Farides del Carmen Lamadrid Feris

\title{
Relações entre corticosterona, cativeiro como estressor e a resposta imune inata em anuros
}

\author{
Relationship between corticosterone, \\ captivity as stressor and the immune innate \\ response in anurans
}

São Paulo, 2021 
Farides del Carmen Lamadrid Feris

\section{Relações entre corticosterona, cativeiro como estressor e a resposta imune inata em anuros}

\section{Relationship between corticosterone, captivity as stressor and the immune innate response in anurans}

Tese apresentada ao Instituto de Biociências da Universidade de São Paulo, para a obtenção do titulo de Doutor em Ciências na Área de Fisiologia Geral.

Orientador: Prof. Dr. Fernando Ribeiro Gomes

São Paulo 
Ficha catalográfica elaborada pelo Serviço de Biblioteca do Instituto de Biociências da USP, com os dados fornecidos pelo (a) autor (a) no formulário:

'https://biblioteca.ib.usp.br/ficha-catalografica/src/ficha.php'

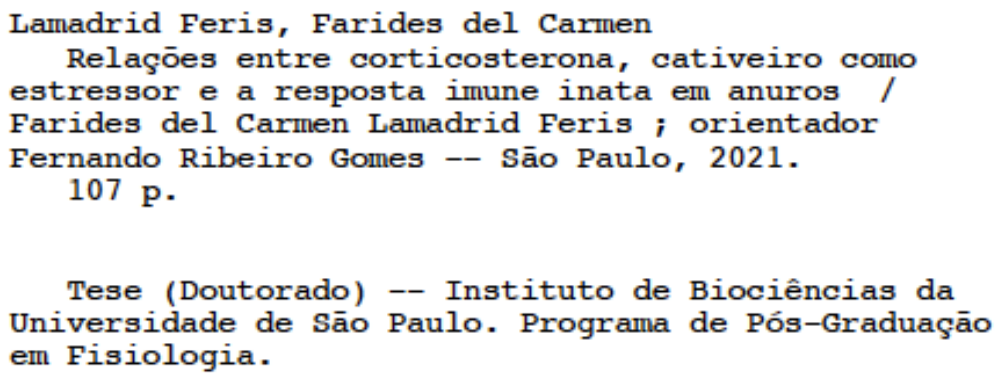

1. Corticosterona. 2. Anuros. 3. Cativeiro. 4 Microbiota Cutânea. 5. Secreçōes Cutâneas. I. Ribeiro Gomes, Fernando, orient. II. Título.

Bibliotecária responsável pela catalogação:

Elisabete da Cruz Neves - CRB - 8/6228

Comissão Julgadora

$\operatorname{Prof}(\mathrm{a}) . \operatorname{Dr}(\mathrm{a})$.

$\operatorname{Prof}(\mathrm{a}) . \operatorname{Dr}(\mathrm{a})$.

$\operatorname{Prof}(a) . \operatorname{Dr}(a)$.

Prof. Dr. Fernando Ribeiro Gomes

Orientador 
"A Deus e a minha família, os quais fizeram possível com seu apoio e amor aquilo que em solidão parecia impossível" 
"Courage is like - it's a habitus, a habit, a virtue: you get it by courageous acts. It's like you learn to swim by swimming. You learn courage by couraging."

(Dra. Marie Maynard Daly)

"Uma nuvem não sabe por que se move em tal direção e em tal velocidade. Sente apenas um impulso que a conduz para esta ou aquela direção. Mas o céu sabe os motivos e os desenhos por trás de todas as nuvens, $e$ você também saberá, quando se erguer o suficiente para ver além dos horizontes"

(Richard Bach) 


\section{AGRADECIMENTOS}

- A Deus por ser meu centro, suporte e guia.

- A meus pais Nora Feris e Hugo Lamadrid pela inspiração que tem sido sempre seu amor e apoio incondicional.

- A minha irmã Gilsa Victoria e minhas sobrinhas porque junto com meus pais são minha corda vital na qual me suporto ainda quando tenho temor da queda. Em especial a mi sobrinha Victoria pelo seu carinho e apoio, sobretudo na ultima fase desta caminhada.

- Aos meus amores, meu filho Paulo Nicolás e meu companheiro Marvin Anganoy, porque se converteram em meu faro e motor, porque com seu amor mudaram minha vida de uma forma inimaginável.

- Ao Prof. Dr. Fernando Ribeiro Gomes, por acreditar em mim e me orientar no processo académico. Pela sua compreensão de todas minhas humanidades me mantendo com a vista no objetivo, por ensinar para mim com seu exemplo a importância da calma e a perseverança

- Ao Prof. Dr. Carlos Navas por ter me mostrado o ponto do início no caminho do doutorado e a alegria com que devemos andar por ele.

- Ao Prof. Dr. Norberto Lopes, quem chegou no momento justo e me mostrou a diferença que faz a disponibilidade real e a empatia pelos outros.

- Ao Prof. MSc. QF. Eduardo Alfonso Martínez Maury quem fosse meu querido amigo, maestro e guia nesta caminhada da vida cientista. Ele marcou meus primeiros passos e me deu a coragem para continuar, quem sempre acreditou em mim até o ultimo momento, mas que hoje não posso abraça-lo e faço este homenagem póstumo para ele.

- Ao Prof. Dr. Taran Grant pelo sequenciamento do banco de bactérias potencialmente benéficas através dos seus projetos FAPESP 590 Procs., 2012/10000-5 e 2018/15425-0

- Aos professores de IB que em algum momento contribuíram para minha formação como pesquisadora através dos seus conhecimentos e aportes ao meu projeto. Pelas portas abertas 
em cada laboratório e disposição técnica dos materiais que permitiram o sucesso do meu projeto.

- Ao Vagner Alberto, o técnico maravilha, pela sua ajuda no campo e laboratório, sua disponibilidade e bom humor sempre.

- Ao Parque Estadual Intervales e seus funcionários por toda a ajuda na logística e atenção no parque.

- A todos do Departamento de Fisiologia Geral, especialmente a Roseli Silva Santos e Erika H. Takamoto de Camargo por trabalho desenvolvido, a ajuda de vocês foi essencial nesta caminhada.

- A meus amigos, aquelas pessoas especiais que fizeram cada dia mais leve, que encheram meu tempo no Brasil de risos, alegrias e experiências maravilhosas que vou atesourar para sempre no meu coração. Cada um de vocês merece uma menção especial, mas ainda se seu nome não está escrito aqui, você sabe que é importante para mim. Para minhas queridas Ecofisio girls (Bruna Casettari, Adriana Barsotti, Renata Vaz, Camila Cabanzo, Stefanny Saruhashi, Daniela Wilwert, Ronyelle Vasconcellos e Débora Silva) as quais tem sido minha rede de apoio ainda na distancia e na pandemia. Às minhas meninas do flow (Isabel Casillas, Karent Gutierrez e Ximena Quecan) por fazer do mundo um local muito mais iluminado e feliz. Ao Alan Góis que hoje comemora no céu, pois junto com Almir Ferreira fizeram que nossa casa sempre tivesse aquele charme de lar. À Johana Becerra, minha querida amiga, estagiaria e companheira de bactérias pelas boas conversas, aprendizado mutuo e toda a diversão.

- Aos meus colegas do laboratório (LaCoFiE), pelas conversas, trocas de ideias e ensinamentos que me ajudaram no caminho do desenvolvimento e aprendizado durante meu doutorado. Em especial a Stefanny Titon e Vânia Assis pelos seus ensinamentos e sugestões acadêmicas. 
Este trabalho foi financiado por:

Fundação de Amparo à Pesquisa do Estado de São Paulo (FAPESP, 2014/16320-7)

Coordenação de Aperfeiçoamento de Pessoal de Nível Superior (CAPES, Código de financiamento 001)

Conselho Nacional de Desenvolvimento Científico e Tecnológico (CNPq, 171088/2017-4)

Programa de Apoio à Pós-Graduação (PROAP) da CAPES

Programa de Pós-graduação em Fisiologia Geral - Departamento de Fisiologia - Instituto de Biociências - USP - São Paulo. 


\section{TABLE OF CONTENTS}

RESUMO GERAL ................................................................................................................................. 11

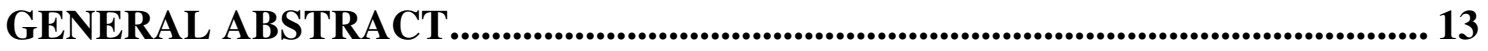

GENERAL INTRODUCTION ............................................................................... 15

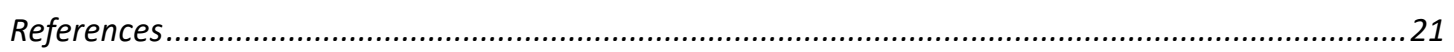

CHAPTER 1. - EMULATING CHRONIC STRESS: A PRACTICAL

APPROACH AND ITS IMMUNOLOGICAL CONSEQUENCES ....Erro! Indicador não definido.

1.1. Abstract Erro! Indicador não definido.

1.2. Introduction........................................................ Erro! Indicador não definido.

1.3. Materials and Methods ....................................... Erro! Indicador não definido.

1.3.1. Animals and Study Site....................................... Erro! Indicador não definido.

1.3.2. Captive Maintenance Conditions........................ Erro! Indicador não definido.

1.3.3. Collecting and Processing Blood Samples. ......... Erro! Indicador não definido.

1.3.4. Experimental Design ............................................. Erro! Indicador não definido.

1.3.5. Silastic Implants............................................... Erro! Indicador não definido.

1.3.6. Hormonal Assay ........................................................ Erro! Indicador não definido.

1.3.7. Bacterial Killing Ability (BKA)............................ Erro! Indicador não definido.

1.3.8. Statistical analysis ........................................... Erro! Indicador não definido.

1.4. Results ...................................................................... Erro! Indicador não definido.

1.5. Discussion ............................................................. Erro! Indicador não definido.

1.6. Conclusions .................................................... Erro! Indicador não definido.

1.7. Acknowledgments.............................................. Erro! Indicador não definido.

1.8. References ............................................................ Erro! Indicador não definido.

CHAPTER 2. - CONSEQUENCES OF CAPTIVITY ON INNATE IMMUNITY AND SKIN BACTERIOME OF SÃO PAULO LEAF FROG .......Erro! Indicador não definido.

2. 1 Abstract Erro! Indicador não definido. 
2. 2 Introduction...................................................... Erro! Indicador não definido.

2.3 Materials and methods ......................................... Erro! Indicador não definido.

2.3.1 Animal Habitat Environment ................................. Erro! Indicador não definido.

2.3.2 Sample Collection ............................................... Erro! Indicador não definido.

2.3.2.1 Skin bacteriome sample collection....................... Erro! Indicador não definido.

2.3.2.2 Potentially beneficial bacteria ............................... Erro! Indicador não definido.

2.3.2.3 Skin bacteriome ......................................................... Erro! Indicador não definido.

2.3.2.4 Collecting and processing blood samples............ Erro! Indicador não definido.

2.3.2.5 Hormonal assay ..................................................... Erro! Indicador não definido.

2.3.2.6 Plasma Bacterial Killing Ability (BKA)............... Erro! Indicador não definido.

2.3.2.7 Cutaneous secretions ......................................... Erro! Indicador não definido.

2.3.2.8 Presence/Absence of Batrachochytrium dendrobatidis .......Erro! Indicador não definido.

2.3.2.9 Bd-inhibitory bacterial database Erro! Indicador não definido.

2.3.3 Sequence and statistical analysis Erro! Indicador não definido.

$2.4 \quad$ Results Erro! Indicador não definido.

2.5 Discussion Erro! Indicador não definido.

2.6 Conclusions Erro! Indicador não definido.

2.7 Acknowledgments. Erro! Indicador não definido.

$2.8 \quad$ References Erro! Indicador não definido.

2.9 Supplementary Material. Erro! Indicador não definido.

GENERAL CONCLUSIONS 20

ANEXO 1 - CERTIFICADO DE APROVAÇÃO DO COMITÊ DE ÉTICA NO USO DE ANIMAIS (CEUA IB/USP). Erro! Indicador não definido. 


\section{RESUMO GERAL}

Anfíbios anuros enfrentam um drástico declínio populacional em nível mundial, devido às mudanças ambientais, perda de habitat e doenças infeciosas emergentes. Essas ameaças representam estressores capazes de gerar respostas crônicas com consequências letais aos anuros. As respostas fisiológicas a estressores podem gerar efeitos imunomodulatórios complexos, que dependem da duração e da intensidade do aumento da concentração plasmática de glicocorticoides (GCs) em sua decorrência. Os efeitos tendem a ser imunoestimulatórios em resposta a estressores agudos e imunossupressores em resposta a estressores crônicos. O objetivo dessa tese foi compreender o impacto do aumento experimental da concentração plasmática de GCs e do cativeiro como estressor, sobre a resposta imune inata e microbiota da pele dos anfíbios anuros. No primeiro capítulo da tese, foi investigado se é possível emular experimentalmente níveis crônicos de corticosterona (CORT) para avaliar seus efeitos sobre a imunidade inata em indivíduos de Rhinella ornata, espécie de sapo associada a regiões florestadas do Brasil. Para tanto, sapos foram implantados subcutaneamente com tubos silásticos contendo CORT (grupo experimental) e tubos silásticos vazios (grupo controle). Amostras de plasma foram obtidas a cada 5 dias após o implante, durante 15 dias, para estimar a concentração de CORT e a capacidade bactericida plasmática (CBP) contra Aeromonas hydrophila. $\mathrm{O}$ tratamento aplicado aumentou a concentração plasmática de CORT ao longo do período experimental e resultou em aumento do CBP do dia 1 ao dia 10 pós-implante, e uma redução da CBP no dia 15 pós-implante. Esses resultados evidenciaram que os implantes de CORT elevaram a concentração de CORT no plasma de maneira crônica, levando à imunomudulação complexa ao longo do tempo experimental. No segundo capítulo da tese, foi investigado se a manutenção em cativeiro de indivíduos da perereca das folhas (Phyllomedusa distincta) resultou em estresse, gerando impactos sobre a imunidade inata e a composição de bactérias da pele. Brevemente, indivíduos de $P$. distincta foram mantidos em cativeiro por 28 dias e amostrados a cada 7 dias. Foram coletadas amostras de sangue, secreções cutâneas, e microbiota da pele. A manutenção em cativeiro não alterou a concentração 
plasmática de CORT, mas reduziu a CBP, incrementou a riqueza de sinais iônicas nas secreções cutâneas e alterou a estrutura do bacterioma da pele, diminuindo a diversidade e abundância gerais. As bactérias potencialmente benéficas contra A. hydrophila e B. dendrobatidis aumentaram em cativeiro. O bacterioma das amostras do campo foi mais parecido com o do último dia em cativeiro, evidenciando uma tendência à resiliência das comunidades. Após a submissão experimental aos estressores (tubos silásticos e cativeiro), as duas espécies mostraram diminuição da CBP, mas só os sapos implantados mostraram aumento da CORT. Esses resultados indicam que o uso de implantes de CORT é um estressor para os sapos, sendo capaz de ativar o eixo HHI, aumentando a secreção de CORT e estimulando a função imunitária no inicio e diminuindo ela com o tempo. Adicionalmente, as pererecas de folha apresentam uma função imune inata plasmática menor se comparada à dos sapos, e elevada ao nível cutâneo o que poderia aumentar seu valor adaptativo no seu ambiente nativo e favorecer o sucesso frente a patógenos emergentes.

Palavras chave: Anuros, Corticosterona, Cativeiro, Microbiota cutânea, Secreções Cutâneas. 


\section{GENERAL ABSTRACT}

Amphibians anuran face a dramatic population decline worldwide, because of environmental changes, loss of habitat, and emerging infectious diseases. These threats represent stressors capable of producing chronic responses with lethal consequences to frogs. The physiological responses to stressors can generate complex immunomodulatory effects, which depend on the duration and intensity of the increase in the plasma concentration of glucocorticoids (GCs). The effects lean to be immunostimulatory in response to acute stressors and immunosuppressive in response to chronic stressors. The aim of this thesis was to understand the impact of the experimental increase in the plasma concentration of GCs and captivity as stressors, on the innate immune response and skin microbiota of anuran amphibians. In the first chapter of this thesis, we investigated whether it is possible to emulate experimentally chronic levels of corticosterone (CORT) to evaluate its effects on innate immunity in individuals of Rhinella ornata, a species of toad associated with forested regions of Brazil. For this purpose, we implanted the toads subcutaneously with silastic tubes containing CORT (experimental group) and empty silastic tubes (control group). We got plasma samples every 5 days after implantation, for 15 days, to estimate CORT concentration and plasma bactericidal capacity (BKA) against Aeromonas hydrophila. The applied treatment increased the plasma CORT concentration throughout the experimental period and resulted in an increase in BKA from day 1 to day 10 post-implantation, and a reduction in BKA on day 15 post-implantation. These results showed that the CORT implants chronically increased the concentration of CORT in the plasma, leading to complex immunomodulation over the experimental time. The second chapter of the thesis investigated whether the maintenance in captivity of individuals of the leaf frog (Phyllomedusa distincta) resulted in stress, generating impacts on the innate immunity and the composition of skin bacteria. Briefly, individuals of $P$. distincta were 
kept in captivity for 28 days and sampled every 7 days. Blood samples, skin secretions, and skin microbiota were collected. Maintenance in captivity did not alter the plasma concentration of CORT, but reduced BKA, increased the richness of signals in skin secretions, and altered the structure of the skin bacteriome, decreasing overall diversity and abundance. The potentially beneficial bacteria against A. hydrophila and Batrachochytrium dendrobatidis increased in captivity. The bacteriome of the samples from the field was more similar to that of the last day in captivity, showing a tendency to resilience in the communities. After experimental submission to stressors (silastic tubes and captivity), both species showed a decrease in BKA, but only implanted toads showed an increase in CORT. These results indicate that the use of CORT implants is a stressor for anurans, being able to activate the HPA/I axis, increasing the secretion of CORT and stimulating immune function in the beginning, and decreasing it through time. Additionally, leaf frogs have a lower plasma innate immune function compared to that of toads but elevated at the cutaneous level, which could increase their fitness in their native environment and facilitate success against emerging pathogens.

Keywords: Anurans, Corticosterone, Captivity, Skin microbiota, Cutaneous Secretions 


\section{GENERAL INTRODUCTION}

Under stress conditions, the hypothalamus-pituitary-interrenal axis (HPA/I) is activated in vertebrates, leading to an increase in circulating levels of glucocorticoids (GCs) (Sapolsky, Romero, and Munck 2000), with corticosterone (CORT) as the main glucocorticoid present in amphibians (Rollins-Smith 2017). The production of GCs in response to stressors and their immunological effects vary depending on the duration and intensity of the stressor event. Short-term stressors activate the HPA/I axis modulating several physiological functions, and contributing to integrative and adaptive responses. Acute stress response enhances leukocytes mobilization from lymphoid organs to circulation; mainly Natural Killers cells and granulocytes (Dhabhar 2009; Viswanathan and Dhabhar 2005; Dhabhar 2002; Dhabhar and McEwen 1997; Tatiersky et al. 2015), increases the metabolic rate (DuRant et al. 2008), anti-predator behaviors (Thaker, Lima, and Hews 2009; Ohmer, Robertson, and Zamudio 2009) and suppress the reproductive hormones (Davies et al. 2016; Ricciardella et al. 2010; Zamudio et al. 2009) among other effects. Nevertheless, long-term activation of the HPA/I axis under chronic stress conditions have harmful effects, including immunosuppression (Dhabhar 2009; McEwen and Stellar 1993). Also, GCs immunosuppressive effects include inhibition of synthesis, reallocation and efficiency of various cytokines and other mediators that promote immune response and inflammatory reactions, and atrophy lymphoid tissues, particularly of the thymus (Sapolsky, Romero, and Munck 2000; Wiegers and Reul 1998; Simmaco et al. 1998; Garvy et al. 1993). In this way, GCs show complex immunomodulatory effects, including bimodal effects associated with acute and chronic responses (Dhabhar 2009; Sapolsky, Romero, and Munck 2000; Munck, Gurye, and Holbrook 1984).

Studies with experimental manipulations of GCs levels in amphibians have contributed to understanding acute and chronic stress response and its immunological 
consequences (Crossin et al. 2016). Many advances in the understanding the relation between GCs and different with phenotypic traits in wild animal are correlational, but experimental manipulation of GCs is necessary to stablish causality (van Kesteren et al. 2019). In anurans, transdermal applications have been used to manipulate levels of CORT and to study immune consequences of acute increased corticosterone plasma levels (Kaiser et al. 2015; Gardner et al. 2018; Madelaire, Cassettari, and Gomes 2019; Titon et al. 2019; Assis et al. 2017, 2015). However, daily CORT transdermal application in the toad Rhinella icterica did not induce chronic CORT plasma levels (Assis et al. 2017). Experimental treatments capable of maintaining constant dose and release rate of GCs are necessary to induce chronically high plasma levels of these hormones (Quispe et al. 2015; Crossin et al. 2016). Silastic subcutaneous implants are good alternatives to induce continuous stimulation of endocrine axis, e. g. hypothalamic-pituitary-gonad (HPG) axis (Quispe et al. 2015; Koresh, Matas, and Koren 2016; Tamaru et al. 1990), and the HPA/I axis (Juneau, Gilmour, and Blouin-Demers 2015; Falso et al. 2015; Bonier et al. 2009). Using endocrine treatments for observing immunomodulatory consequences is an interesting approach. Previous studies suggested that researches with experimental manipulation of GCs must have an appropriate theoretical framework through which can correctly interpret the increased produced by this method (L. Romero 2004; Crossin et al. 2016). Rhinella ornata, is a non-threatened Brazilian toad from the Atlantic forest (Baldissera 2010), for which it was previously observed a negative association between plasma bacterial killing ability (BKA) and CORT plasma levels (F. R. Gomes et al. 2012). It is also known that dehydration triggers a pronounced stress response (Barsotti et al. 2019), exposure to short and mid-term stressors results in immuno-enhancing effects, and long-term captivity produce immunosuppressive effect (Titon et al. 2019) in $R$. ornata. 
Based in all that information, we chosen this species as the model in our research about experimental manipulation of CORT levels.

The chronic activation of HPA/I axis and its immune consequences is a topic particularly relevant for amphibians because of the worldwide declining of their populations caused by climate change, habitat loss and emerging infectious diseases (Carey, Cohen, and Rollins-Smith 1999; Daszak et al. 1999; Daszak, Cunningham, and Hyatt 2003). Diseases like Chytridiomycosis (caused by the fungus Batrachochytrium dendrobatidis) and red-leg syndrome (bacterial septicemia that include Aeromonas hydrophila (Pessier 2002)) have decimated and disappeared entire populations and species (Daszak, Cunningham, and Hyatt 2003; James et al. 2015; Scheele et al. 2019) forcing to transfer the survivors populations to captivity conditions. Besides being a source of amphibian declines, these diseases share the skin as the target organ. The skin is the first physical barrier and protect against predators, injuries and pathogens (Varga, Bui-Marinos, and Katzenback 2019; Haslam et al. 2014). In amphibian anurans, the skin produce several substances as antimicrobial peptides (AMPs) (Conlon, Iwamuro, and King 2009), together with alkaloids (Toledo and Jared 1995; A. A. Gomes et al. 2007), lipids and polysaccharides (Elkan 1968). AMPs are considered effector molecules of innate immunity (Varga, Bui-Marinos, and Katzenback 2019). Stress, injury, or infection can induce the secretion of constitutive AMPs from granular glands in anurans (Heimlich, Harrison, and Mason 2014; Pask, Woodhams, and Rollins-Smith 2012). Cortisone treatment blocked de novo synthesis of all AMPs, blocking nuclear factor kappa-beta (NF-kB) by induction of inhibitor of NF-jB (IkBa) synthesis according to (Boman 2003). Then, the AMPs can be altered by the activation of the HPA/I axis (Radek et al. 2010) responding to increased circulating GCs levels (Tatiersky et al. 2015; Simmaco et al. 1997). 
Together with the immune system, the skin microbiome can regulate pathogens, through competition by resources and the producing antimicrobial metabolites (Barnes, Carter, and Lewis 2020; Byrd, Belkaid, and Segre 2018; Kearns et al. 2017; Colombo et al. 2015; Myers et al. 2012) conferring it to skin microbial communities a protective role (Bletz et al. 2013; Jiménez and Sommer 2017; Burkart et al. 2017; Colombo et al. 2015). Nowadays, the perception of skin as an ecosystem with living biological and physical components occupying diverse habitats granted the advanced understanding of the delicate balance between host and microorganism (Grice and Segre 2011). Many studies with anuran skin microbiome revealed several commensal bacteria produced metabolites capable to inhibit the growth of known pathogens (Woodhams et al. 2016; Burkart et al. 2017). Researches with skin commensal bacteria in anurans sought antifungal bacteria and documented them in the Antifungal Isolates Database (Woodhams et al. 2015), considering that the fungus $B$. dendrobatidis is the major cause of worldwide anuran declines (Scheele et al. 2019). The bacterial metabolites can act synergistically with cutaneous AMPs to inhibit the skin pathogens (Myers et al. 2012). Several morphotypes of four families of commensal skin bacteria were identified in Phyllomedusa distincta with activity against bacterial pathogens (Brito de Assis et al. 2016), although the possible inhibitory effects on the pathogen fungus $B$. dendrobatidis remain unexplored. Also, this species of frog have different AMPs against bacteria, such as Phylloseptins and Dermaseptins (Brito de Assis et al. 2016; C. V. . Batista et al. 2001; Silva et al. 2008; Roberto et al. 2008). Thus, $P$. distincta represents an ideal model for investigation of multifaceted innate immunity approaches, which is critical to explaining the complex host-pathogen-environment interactions at the skin interface and their part in amphibian susceptibility to emerging infectious diseases (Varga et al., 2019). The physiological state of the amphibian host must be considered to understand their ability to deal with emerging 
infectious diseases, given that allows to discern the direct consequences of physiological mediator levels on immunity and therefore on the microbiome of the skin. Also, since captivity may be a long-term stressor for anurans (Titon et al. 2017), it is important to understand its immune consequences to guarantee the viability of ex-situ programs and the eventual success of reintroduction initiatives (Zippel et al. 2011; McMahon et al. 2014; Alford and Richards 1999). Captivity may be a chronic stressor for toads, decreasing BKA and testosterone levels (Assis et al. 2017). Although, many studies with amphibians were focused on acute stress responses and its immune consequences (Narayan, Cockrem, and Hero 2013; Madelaire, Cassettari, and Gomes 2019; Assis et al. 2015; Ricciardella et al. 2010; Homan, Reed, and Romero 2003).

In the first chapter (Emulating chronic stress: A practical approach and its immunological consequences) we investigated if the use of subcutaneous silastic implants of CORT allows achieving chronically elevated CORT levels in $R$. ornata, and if this endocrine treatment can promote changes on a parameter of the innate immune response, the BKA. In the second chapter (Consequences of captivity on innate immunity and skin bacteriome of São Paulo leaf frog) we evaluated how captivity maintenance affects physiological state, immune function, and the structure of skin bacteriome, focusing especially on potentially beneficial bacteria against emerging pathogens. 


\section{GENERAL CONCLUSIONS}

Corticosterone silastic implants produced sustained increased corticosterone plasma levels of Rhinella ornata, inducing mid-term immunoenhancing and long-term immunosuppressive effects on the ability of plasma to kill Aeromonas hydrophila, an anuran opportunistic pathogen. In this way, corticosterone silastic implants provide a useful experimental tool to study and unravel the underlying immunomodulation mechanisms of this hormone in anurans.

Even without changing corticosterone plasma levels, the maintenance of Phyllomedusa distincta in captivity shifted innate immune function. Captivity maintenance decreased the plasma ability to kill the opportunistic bacteria A. hydrophila, increased ionic signals on skin secretions, and increased the abundance and prevalence of Anti-Ah and Anti-Bd bacteria. Then, experimental researches and conservation programs with anurans must consider time and condition of captivity maintenance because the consequences observed in the innate immune function and skin bacteriome can determine the success of future reintroduction programs.

Considering the sharp decline that amphibian populations have been suffering, mainly due to interacting effects of climate change, emerging infectious diseases and habitat loss, it is important to assess the effects of these stressors on amphibian innate immune response and microbiota for the planning and design of conservation strategies. Future studies, involving exposure to stressors for a longer period, and their immunological consequences, would be interesting to continue understanding these relationships. 


\section{References}

Alford, R. A., \& Richards, S. J. (1999). Global amphibian declines: A problem in applied ecology. Annual Review of Ecology and Systematics, 30, 133-165. https://doi.org/10.1146/annurev.ecolsys.30.1.133

Assis, V. R., Monteiro Titon, S. C., Teixeira Queiroz-Hazarbassanov, N. G., de Oliveira Massoco, C., \& Ribeiro Gomes, F. (2017). Corticosterone transdermal application in toads ( Rhinella icterica ): Effects on cellular and humoral immunity and steroid plasma levels. Journal of Experimental Zoology Part A: Ecological and Integrative Physiology, 327(4), 200-213. https://doi.org/10.1002/jez.2093

Assis, V. R., Titon, S. C. M., Barsotti, A. M. G., Titon, B., Gomes, F. R., Monteirotiton, S. C., Barsotti, A. M. G., Titon, B., Gomes, F. R., De Assis, V. R., Titon, S. C. M., Barsotti, A. M. G., Titon, B., \& Gomes, F. R. (2015). Effects of Acute Restraint Stress, Prolonged Captivity Stress and Transdermal Corticosterone Application on Immunocompetence and Plasma Levels of Corticosterone on the Cururu Toad (Rhinella icterica). PloS One, 10(4), e0121005. https://doi.org/10.1371/journal.pone.0121005

Baldissera, F. (2010). Rhinella ornata. The IUCN Red List of Threatened Species 2010: e.T61754A12554682. The IUCN Red List of Threatened Species 2010: E.T61754A12554682. http://www.iucnredlist.org/details/61754/0

Barnes, E. M., Carter, E. L., \& Lewis, J. D. (2020). Predicting Microbiome Function Across Space Is Confounded by Strain-Level Differences and Functional Redundancy Across Taxa. Frontiers in Microbiology, 11. https://doi.org/10.3389/fmicb.2020.00101

Barsotti, A. M. G., Titon Junior, B., Titon, S. C. M., \& Gomes, F. R. (2019). Dehydration as a stressor in toads (Rhinella ornata). Journal of Experimental Zoology Part A: Ecological and Integrative Physiology, 331(3), 168-174. https://doi.org/10.1002/jez.2250

Batista, C. V. ., Scaloni, A., Rigden, D. J., Silva, L. R., Rodrigues Romero, A., Dukor, R., Sebben, A., Talamo, F., \& Bloch, C. (2001). A novel heterodimeric antimicrobial peptide from the tree-frog Phyllomedusa distincta. FEBS Letters, 494(1-2), 85-89. https://doi.org/10.1016/S0014-5793(01)02324-9

Bletz, M. C., Loudon, A. H., Becker, M. H., Bell, S. C., Woodhams, D. C., Minbiole, K. P. C., \& Harris, R. N. (2013). Mitigating amphibian chytridiomycosis with bioaugmentation: characteristics of effective probiotics and strategies for their selection and use. Ecology Letters, 16(6), 807-820. https://doi.org/10.1111/ele.12099

Boman, H. G. (2003). Antibacterial peptides: basic facts and emerging concepts. Journal of Internal Medicine, 254(3), 197-215. https://doi.org/doi:10.1046/j.13652796.2003.01228.x

Bonier, F., Martin, P. R., Moore, I. T., \& Wingfield, J. C. (2009). Do baseline glucocorticoids predict fitness? In Trends in Ecology and Evolution (Vol. 24, Issue 11, pp. 634-642). Elsevier Current Trends. https://doi.org/10.1016/j.tree.2009.04.013

Brito de Assis, A., Dos Santos, C., Dutra, F. P., de Oliveira Motta, A., Costa, F. S., Navas, C. A., Magalhães, B. S., \& Barreto, C. C. (2016). Assessing Antibacterial Potential of Components of Phyllomedusa distincta Skin and its Associated Dermal Microbiota. Journal of Chemical Ecology. https://doi.org/10.1007/s10886016-0665-3 
Burkart, D., Flechas, S. V., Vredenburg, V. T., \& Catenazzi, A. (2017). Cutaneous bacteria, but not peptides, are associated with chytridiomycosis resistance in Peruvian marsupial frogs. Animal Conservation, 20(6), 483-491. https://doi.org/10.1111/acv.12352

Byrd, A. L., Belkaid, Y., \& Segre, J. A. (2018). The human skin microbiome. Nature Publishing Group, 16. https://doi.org/10.1038/nrmicro.2017.157

Carey, C., Cohen, N., \& Rollins-Smith, L. (1999). Amphibian declines: An immunological perspective. Developmental and Comparative Immunology, 23(6), 459-472. https://doi.org/10.1016/S0145-305X(99)00028-2

Colombo, B. M., Scalvenzi, T., Benlamara, S., \& Pollet, N. (2015). Microbiota and Mucosal Immunity in Amphibians. Frontiers in Immunology, 6(March), 1-15. https://doi.org/10.3389/fimmu.2015.00111

Conlon, J. M., Iwamuro, S., \& King, J. D. (2009). Dermal cytolytic peptides and the system of innate immunity in anurans. Annals of the New York Academy of Sciences, 1163, 75-82. https://doi.org/10.1111/j.1749-6632.2008.03618.x

Crossin, G. T., Love, O. P., Cooke, S. J., \& Williams, T. D. (2016). Glucocorticoid manipulations in free-living animals: Considerations of dose delivery, life-history context and reproductive state. Functional Ecology, 30(1), 116-125. https://doi.org/10.1111/1365-2435.12482

Daszak, P., Berger, L., Cunningham, A. A., Hyatt, A. D., Earl Green, D., \& Speare, R. (1999). Emerging infectious diseases and amphibian population declines. Emerging Infectious Diseases, 5(6), 735-748. https://doi.org/10.3201/eid0506.990601

Daszak, P., Cunningham, A. A., \& Hyatt, A. D. (2003). Infectious disease and amphibian population declines. In Diversity and Distributions (Vol. 9, Issue 2, pp. 141-150). Wiley/Blackwell (10.1111). https://doi.org/10.1046/j.14724642.2003.00016.x

Davies, S., Noor, S., Carpentier, E., \& Deviche, P. (2016). Innate immunity and testosterone rapidly respond to acute stress, but is corticosterone at the helm? Journal of Comparative Physiology B: Biochemical, Systemic, and Environmental Physiology, 186(7), 907-918. https://doi.org/10.1007/s00360-016-0996-y

Dhabhar, F. S. (2002). Stress-induced augmentation of immune function-The role of stress hormones, leukocyte trafficking, and cytokines. Brain, Behavior, and Immunity, 16(6), 785-798. https://doi.org/10.1016/S0889-1591(02)00036-3

Dhabhar, F. S. (2009). Enhancing versus Suppressive Effects of Stress on Immune Function: Implications for Immunoprotection and Immunopathology Enhancing vs. Suppressive Effects of Stress on Immune Function. Neuroimmunomodulation, 16(5), 300-317. https://doi.org/10.1159/000216188

Dhabhar, F. S., \& McEwen, B. S. (1997). Acute stress enhances while chronic stress suppresses cell-mediated immunity in vivo: A potential role for leukocyte trafficking. Brain, Behavior, and Immunity, 11(4), 286-306. https://doi.org/10.1006/brbi.1997.0508

DuRant, S. E., Romero, L. M., Talent, L. G., \& Hopkins, W. A. (2008). Effect of exogenous corticosterone on respiration in a reptile. General and Comparative Endocrinology, 156(1), 126-133. https://doi.org/10.1016/j.ygcen.2007.12.004

Elkan, E. (1968). Mucopolysacarides in the anuran defence against desiccation. J. Zool., $155,19-53$.

Falso, P. G., Noble, C. A., Diaz, J. M., \& Hayes, T. B. (2015). The effect of long-term corticosterone treatment on blood cell differentials and function in laboratory and wild-caught amphibian models. General and Comparative Endocrinology, 212, 
73-83. https://doi.org/10.1016/j.ygcen.2015.01.003

Gardner, S., Assis, V. R., Zhao, H., Gomes, F. R., Peatman, E., \& Mendonça, M. T.

(2018). Differential gene expression to an LPS challenge in relation to exogenous corticosterone in the invasive cane toad (Rhinella marina). Developmental and Comparative Immunology, 88(April), 114-123.

https://doi.org/10.1016/j.dci.2018.07.016

Garvy, B. A., King, L. E., Telford, W. G., Morford, L. A., \& Fraker, P. J. (1993). Chronic elevation of plasma corticosterone causes reductions in the number of cycling cells of the B lineage in murine bone marrow and induces apoptosis. Immunology, 80(4), 587-592.

Gomes, A. A., Giri, B., Saha, A., Mishra, R., Dasgupta, S. C., Debnath, A., \& Gomes, A. A. (2007). Bioactive molecules from amphibian skin: Their biological activities with reference to therapeutic potentials for possible drug development. In Indian Journal of Experimental Biology (Vol. 45, Issue 7, pp. 579-593).

Gomes, F. R., Oliveira, R. V., Assis, V. R., Junior, B. T., Moretti, E. H., \& Mendonça, M. T. (2012). Interspecific Variation in Innate Immune Defenses and Stress Response of Toads from Botucatu (São Paulo, Brazil). South American Journal of Herpetology, 7(1), 1-8. https://doi.org/10.2994/057.007.0101

Grice, E. A., \& Segre, J. A. (2011). The skin microbiome. Nature Reviews Microbiology, 9(4), 244-253. https://doi.org/10.1038/nrmicro2537

Haslam, I. S., Roubos, E. W., Mangoni, M. L., Yoshizato, K., Vaudry, H., Kloepper, J. E., Pattwell, D. M., Maderson, P. F. A., \& Paus, R. (2014). From frog integument to human skin: Dermatological perspectives from frog skin biology. Biological Reviews, 89(3), 618-655. https://doi.org/10.1111/brv.12072

Heimlich, D., Harrison, A., \& Mason, K. (2014). Host Antimicrobial Peptides in Bacterial Homeostasis and Pathogenesis of Disease. Antibiotics, 3(4), 645-676. https://doi.org/10.3390/antibiotics3040645

Homan, R. N., Reed, J. M., \& Romero, L. M. (2003). Corticosterone concentrations in free-living spotted salamanders (Ambystoma maculatum). General and Comparative Endocrinology, 130(2), 165-171. http://www.ncbi.nlm.nih.gov/pubmed/12568794

James, T. Y., Toledo, L. F., Rödder, D., da Silva Leite, D., Belasen, A. M., BetancourtRomán, C. M., Jenkinson, T. S., Soto-Azat, C., Lambertini, C., Longo, A. V., Ruggeri, J., Collins, J. P., Burrowes, P. A., Lips, K. R., Zamudio, K. R., \& Longcore, J. E. (2015). Disentangling host, pathogen, and environmental determinants of a recently emerged wildlife disease: Lessons from the first 15 years of amphibian chytridiomycosis research. Ecology and Evolution, 5(18), 4079-4097. https://doi.org/10.1002/ece3.1672

Jiménez, R. R., \& Sommer, S. (2017). The amphibian microbiome: natural range of variation, pathogenic dysbiosis, and role in conservation. In Biodiversity and Conservation. https://doi.org/10.1007/s10531-016-1272-x

Juneau, V., Gilmour, K. M., \& Blouin-Demers, G. (2015). Cocoa Butter Injections, but not Sealed or Perforated Silastic Implants, of Corticosterone can be used to Chronically Elevate Corticosterone in Free-Living Painted Turtles (Chrysemys picta). Journal of Herpetology, 49(4), 662-670. https://doi.org/10.1670/13-125

Kaiser, K., Devito, J., Jones, C. G., Marentes, A., Perez, R., Umeh, L., Weickum, R. M., McGovern, K. E., Wilson, E. H., \& Saltzman, W. (2015). Reproductive and immune effects of chronic corticosterone treatment in male White's treefrogs, Litoria caerulea. Conservation Physiology, 3(1), cov022. https://doi.org/10.1093/conphys/cov022 
Kearns, P. J., Fischer, S., Fernández-Beaskoetxea, S., Gabor, C. R., Bosch, J., Bowen, J. L., Tlusty, M. F., \& Woodhams, D. C. (2017). Fight fungi with fungi: Antifungal properties of the amphibian mycobiome. Frontiers in Microbiology, 8(DEC), 2494. https://doi.org/10.3389/fmicb.2017.02494

Koresh, E., Matas, D., \& Koren, L. (2016). Experimental elevation of wildlife testosterone using silastic tube implants. Research in Veterinary Science, 108, 1-7. https://doi.org/10.1016/j.rvsc.2016.07.005

Madelaire, C. B., Cassettari, B. de O., \& Gomes, F. R. (2019). Immunomodulation by testosterone and corticosterone in toads: Experimental evidences from transdermal application. General and Comparative Endocrinology, 273(October 2017), 227235. https://doi.org/10.1016/j.ygcen.2018.09.005

McEwen, B. S., \& Stellar, E. (1993). Stress and the Individual: Mechanisms Leading to Disease. Archives of Internal Medicine, 153(18), 2093-2101. https://doi.org/10.1001/archinte.1993.00410180039004

McMahon, T. A., Sears, B. F., Venesky, M. D., Bessler, S. M., Brown, J. M., Deutsch, K., Halstead, N. T., Lentz, G., Tenouri, N., Young, S., Civitello, D. J., Ortega, N., Fites, J. S., Reinert, L. K., Rollins-Smith, L. A., Raffel, T. R., \& Rohr, J. R. (2014). Amphibians acquire resistance to live and dead fungus overcoming fungal immunosuppression. Nature, 511(7508), 224-227. https://doi.org/10.1038/nature13491

Munck, A., Gurye, P. M., \& Holbrook, N. J. (1984). Physiological Functions of Glucocorticoids in Stress and their Relationship to Pharmacological Actions. Endocrine Reviews, 5, 25-44.

Myers, J. M., Ramsey, J. P., Blackman, A. L., Nichols, A. E., Minbiole, K. P. C., \& Harris, R. N. (2012). Synergistic Inhibition of the Lethal Fungal Pathogen Batrachochytrium dendrobatidis: The Combined Effect of Symbiotic Bacterial Metabolites and Antimicrobial Peptides of the Frog Rana muscosa. Journal of Chemical Ecology, 38(8), 958-965. https://doi.org/10.1007/s10886-012-0170-2

Narayan, E. J., Cockrem, J. F., \& Hero, J. (2013). Repeatability of baseline corticosterone and short-term corticosterone stress responses, and their correlation with testosterone and body condition in a terrestrial breeding anuran (Platymantis vitiana). Comparative Biochemistry and Physiology, Part A, 165(2), 304-312. https://doi.org/10.1016/j.cbpa.2013.03.033

Ohmer, M. E., Robertson, J. M., \& Zamudio, K. R. (2009). Discordance in body size, colour pattern, and advertisement call across genetically distinct populations in a Neotropical anuran (Dendropsophus ebraccatus). Biological Journal of the Linnean Society, 97(2), 298-313. https://doi.org/10.1111/j.10958312.2009.01210.x

Pask, J. D., Woodhams, D. C., \& Rollins-Smith, L. A. (2012). The ebb and flow of antimicrobial skin peptides defends northern leopard frogs (Rana pipiens) against chytridiomycosis. Global Change Biology, 18(4), 1231-1238. https://doi.org/10.1111/j.1365-2486.2011.02622.x

Pessier, A. P. (2002). An overview of amphibian skin disease. Seminars in Avian and Exotic Pet Medicine, 11(3), 162-174. https://doi.org/10.1053/saep.2002.123980

Quispe, R., Trappschuh, M., Gahr, M., \& Goymann, W. (2015). Towards more physiological manipulations of hormones in field studies: Comparing the release dynamics of three kinds of testosterone implants, silastic tubing, time-release pellets and beeswax. General and Comparative Endocrinology, 212, 100-105. https://doi.org/10.1016/j.ygcen.2015.01.007

Radek, K. A., Elias, P. M., Taupenot, L., Mahata, S. K., O’Connor, D. T., Gallo, R. L., 
Daniel, T., Connor, O., \& Gallo, R. L. (2010). Neuroendocrine nicotinic receptor activation increases susceptibility to bacterial infections by suppressing antimicrobial peptide production. Cell Host and Microbe, 7(4), 277-289. https://doi.org/10.1016/j.chom.2010.03.009.Neuroendocrine

Ricciardella, L. F., Bliley, J. M., Feth, C. C., \& Woodley, S. K. (2010). Acute stressors increase plasma corticosterone and decrease locomotor activity in a terrestrial salamander (Desmognathus ochrophaeus). Physiology and Behavior, 101(1), 8186. https://doi.org/10.1016/j.physbeh.2010.04.022

Roberto, J., Leite, S. A., Brand, G. D., Silva, L. P., Kückelhaus, S. A. S., Bento, W. R. C., Araújo, A. L. T., Martins, G. R., Lazzari, A. M. A. M., Bloch, C., Leite, J. R. S. A., Brand, G. D., Silva, L. P., K??ckelhaus, S. A. S., Bento, W. R. C., Ara??jo, A. L. T., Martins, G. R., Lazzari, A. M. A. M., \& Bloch, C. (2008). Dermaseptins from Phyllomedusa oreades and Phyllomedusa distincta: Secondary structure, antimicrobial activity, and mammalian cell toxicity. Comparative Biochemistry and Physiology - A Molecular and Integrative Physiology, 151(3), 336-343. https://doi.org/10.1016/j.cbpa.2007.03.016

Rollins-Smith, L. A. (2017). Amphibian immunity-stress, disease, and climate change. Developmental and Comparative Immunology, 66, 111-119. https://doi.org/10.1016/j.dci.2016.07.002

Romero, L. (2004). Physiological stress in ecology: lessons from biomedical research. Trends in Ecology \& Evolution, 19, 249-255.

Sapolsky, R. M., Romero, L. M., \& Munck, A. U. (2000). How do glucocorticoids influence stress responses? Integrating permissive, suppressive, stimulatory, and preparative actions. Endocrine Reviews, 21(1), 55-89. https://doi.org/10.1210/er.21.1.55

Scheele, B. C., Pasmans, F., Skerratt, L. F., Berger, L., Martel, A., Beukema, W., Acevedo, A. A., Burrowes, P. A., Carvalho, T., Catenazzi, A., De La Riva, I., Fisher, M. C., Flechas, S. V., Foster, C. N., Frías-Álvarez, P., Garner, T. W. J., Gratwicke, B., Guayasamin, J. M., Hirschfeld, M., ... Canessa, S. (2019). Amphibian fungal panzootic causes catastrophic and ongoing loss of biodiversity. Science, 363(6434), 1459-1463. https://doi.org/10.1126/science.aav0379

Silva, L. P., Leite, J. R. S. A., Brand, G. D., Regis, W. B., Tedesco, A. C., Azevedo, R. B., Freitas, S. M., Bloch, C., Roberto, J., Leite, S. A., Brand, G. D., Regis, W. B., Tedesco, A. C., Azevedo, R. B., Freitas, S. M., \& Bloch, C. (2008). Dermaseptins from Phyllomedusa oreades and Phyllomedusa distincta: Liposomes fusion and / or lysis investigated by fluorescence and atomic force microscopy 25 . Comparative Biochemistry and Physiology - A Molecular and Integrative Physiology, 151(3), 329-335. https://doi.org/10.1016/j.cbpa.2007.02.031

Simmaco, M., Boman, A., Mangoni, M. L., Mignogna, G., Miele, R., Barra, D., \& Boman, H. G. (1997). Effect of glucocorticoids on the synthesis of antimicrobial peptides in amphibian skin. FEBS Letters, 416(3), 273-275. https://doi.org/10.1016/S0014-5793(97)01216-7

Simmaco, M., Mangoni, M. L., Boman, A., Barra, D., Boman, H. G., Simmaco, Mangoni, M. L., Boman, Barra, \& Boman. (1998). Experimental Infections of Rana esculenta with Aeromonas hydrophila: A Molecular Mechanism for the Control of the Normal Flora. Scandinavian Journal of Immunology, 48(4), 357363. https://doi.org/10.1046/j.1365-3083.1998.00407.x

Tamaru, C. S., Lee, C. S., Ha, P. Y., Ginoza, J. M., Aida, K., \& Hanyu, I. (1990). Release rates of steroids from silastic tube implants in vitro and in vivo with juvenile milkfish, Chanos chanos. Aquaculture, 87(1), 91-101. 
https://doi.org/10.1016/0044-8486(90)90213-7

Tatiersky, L., Rollins-Smith, L. A., Lu, R., Jardine, C., Barker, I. K., Clark, M. E., \& Caswell, J. L. (2015). Effect of glucocorticoids on expression of cutaneous antimicrobial peptides in northern leopard frogs (Lithobates pipiens). BMC Veterinary Research, 11(1), 191. https://doi.org/10.1186/s12917-015-0506-6

Thaker, M., Lima, S. L., \& Hews, D. K. (2009). Acute corticosterone elevation enhances antipredator behaviors in male tree lizard morphs. Hormones and Behavior, 56(1), 51-57. https://doi.org/10.1016/j.yhbeh.2009.02.009

Titon, S. C. M., Assis, V. R., Titon Junior, B., Cassettari, B. de O., Fernandes, P. A. C. M., \& Gomes, F. R. (2017). Captivity effects on immune response and steroid plasma levels of a Brazilian toad (Rhinella schneideri). Journal of Experimental Zoology Part A: Ecological and Integrative Physiology, 327(2-3), 127-138. https://doi.org/10.1002/jez.2078

Titon, S. C. M., Titon, B., Barsotti, A. M. G., Gomes, F. R., \& Assis, V. R. (2019). Time-related immunomodulation by stressors and corticosterone transdermal application in toads. PLOS ONE, 14(9), e0222856. https://doi.org/10.1371/journal.pone.0222856

Toledo, R. C., \& Jared, C. (1995). Cutaneous granular glands and amphibian venoms. In Comparative Biochemistry and Physiology -- Part A: Physiology (Vol. 111, Issue 1, pp. 1-29). https://doi.org/10.1016/0300-9629(95)98515-I

van Kesteren, F., Delehanty, B., Westrick, S. E., Palme, R., Boonstra, R., Lane, J. E., Boutin, S., McAdam, A. G., \& Dantzer, B. (2019). Experimental Increases in Glucocorticoids Alter Function of the HPA Axis in Wild Red Squirrels without Negatively Impacting Survival and Reproduction. Physiological and Biochemical Zoology, 92(5), 445-458. https://doi.org/10.1086/705121

Varga, J. F. A., Bui-Marinos, M. P., \& Katzenback, B. A. (2019). Frog skin innate immune defences: Sensing and surviving pathogens. In Frontiers in Immunology (Vol. 10, Issue JAN). Frontiers Media S.A. https://doi.org/10.3389/fimmu.2018.03128

Viswanathan, K., \& Dhabhar, F. S. (2005). Stress-induced enhancement of leukocyte trafficking into sites of surgery or immune activation. Proceedings of the National Academy of Sciences of the United States of America, 102(16), 5808-5813. https://doi.org/10.1073/pnas.0501650102

Wiegers, G. J., \& Reul, J. M. H. M. (1998). Induction of cytokine receptors by glucocorticoids: functional and pathological significance. Trends in Pharmacological Sciences, 19(8), 317-321. https://doi.org/10.1016/S01656147(98)01229-2

Woodhams, D. C., Alford, R. A., Antwis, R. E., Archer, H., Becker, M. H., Belden, L. K., Bell, S. C., Bletz, M., Daskin, J. H., Davis, L. R., Flechas, S. V., Lauer, A., Gonzalez, A., Harris, R. N., Holden, W. M., Hughey, M. C., Ibáñez, R., Knight, R., Kueneman, J., ... McKenzie, V. (2015). Antifungal isolates database of amphibian skin-associated bacteria and function against emerging fungal pathogens. Ecology, 96(2), 595-595. https://doi.org/10.1890/14-1837.1

Woodhams, D. C., Bletz, M., Kueneman, J., \& McKenzie, V. (2016). Managing Amphibian Disease with Skin Microbiota. Trends in Microbiology, 24(3), 161164. https://doi.org/10.1016/j.tim.2015.12.010

Zamudio, S. R., Quevedo-Corona, L., Garcés, L., \& De La Cruz, F. (2009). The effects of acute stress and acute corticosterone administration on the immobility response in rats. Brain Research Bulletin, 80(6), 331-336.

https://doi.org/10.1016/j.brainresbull.2009.09.005 
Zippel, K., Johnson, K., Gagliardo, R., Gibson, R., McFadden, M., Browne, R., Martinez, C., \& Townsend, E. (2011). The amphibian Ark: A global community for ex situ conservation of amphibians. Herpetological Conservation and Biology, 6(3), 340-352. https://www.researchgate.net/publication/260427036 